International Journal on Integrating Technology in Education (IJITE) Vol.5,No.2, June 2016

\title{
Promoting Female Students' Interests in STUDYING WITH EDUCATIONAL TECHNOLOGY
}

\author{
David Blasco \\ Department of Education, National Chung Cheng University, Jia Yi, Taiwan
}

\begin{abstract}
Numerous studies have discussed gender differences in technology education, and have demonstrated that male students have more confidence in using technology than do female students. Female students' lack of interest is due to the pedagogical approaches favoring male values. By contrast, no previous research on the integration of technology in English as a foreign language has investigated gender differences and the level of confidence of students in using technology in the classroom. This study aims to investigate the perceptions of students' use of technology in the field of English applied foreign languages and check their perceptions about the use of computer technology. For this purpose, students enrolled in a conventional class of second year license degree in Applied Foreign Languages were interviewed and answered a questionnaire. The results of this study show that female students are highly likely to gain more confidence when given activities that match their learning interests.
\end{abstract}

\section{KEYWORDS}

Computer, technology, education, gender, foreign applied languages

\section{INTRODUCTION}

According to Wikipedia (2016) [1], the term "Educational Technology" is defined by the Association for Educational Communications and Technology as "the study and ethical practice of facilitating learning and improving performance by creating, using, and managing appropriate technological processes and resources." Educational technology refers to the use of both physical hardware and educational theoretics. It encompasses several domains, including learning theory, computer-based training, online learning, and, where mobile technologies are used, m-learning.

Although Gender differences are discussed in numerous studies, and that they are all unanimous regarding the questions of gender stereotypes (Yau \& Cheng, 2012, p. 2) [2] patriarchy (Zuga, 1999, p. 58; Pujol \& Montenegro, 2013, p. 178) [3] [4] and gender discrimination (Wang, 2012, p. 3) [5] in technology education, the researcher has found no study regarding the gender gap and differences in educational technology, more particularly in the domain of Applied foreign languages and the use of educational technology.

One English class mostly composed of female students, is studying English translation at National Taipei University of Business. Female students have shown little interest in using the available technology in the classroom, and male students tend to be extremely passive. Hence, this descriptive research aims to find out if there are gender gaps and stereotypes between male and female students. As students can participate more in the language learning with multimedia language teaching by improving their motivation and learning interest (Shyamlee \& Phil, 2012, p. 155) [6], it seems relevant to study how these students can be motivated to contribute more to class learning. 
According to Altun (2015, p.1) [7], students learning a foreign language strongly believe that technology-based instruction should be implemented in language learning process, and concludes that technology-based instruction leads to accomplishment. Nevertheless, gender differences have not been mentioned in the literature regarding the learning of applied foreign languages, and the researcher of this study is curious to find out if similar gender differences that female students experience in technology education exist in the learning of applied foreign languages with the use of educational technology.

The paper is organized into the following sections. Section 2 presents the literature review on the subject. Section 3 presents the methodology used for conducting this study. Section 4 presents the results of the study regarding the differences of male and female students' use of technology in applied foreign language studies, followed by a discussion and conclusion in section 5 .

\section{LITERATURE REVIEW}

According to Wajcman (2007, p. 295) [8], the literature on gender and technology has grown to become a broad and diverse field. Today, new opportunities are available to investigate how different groups of women users comprehend ICTs in different real-world locations. Thus, the use of technology should be considered more importance in discussions of gender relations (Pujol \& Montenegro, 2013, p. 175) [4].

Technologies have always had a masculine image value with masculine connotations (Wajcman, 2007, p. 289) [8], and although the internet has been widely used by women, others have ignored it and labeled it as "another toy for the boy" (Faulkner, 2001, p. 80) [9] because they have been led to believe that only men are born to use technology (Wang, 2012, p. 4) [5]. The reason for this is that, according to Wang (2012, p. 3) [5], females have had to face a patriarchic society. Females have yielded to the masculine authority by giving up their gender identity (Wajcman, 2007, p. 289) [8] because they are not only challenged by their peers' criticisms, but also by the discrimination of their teachers who think of them as sexy and not intelligent enough (Wang, 2012, p. 3) [5].

Engineers usually take pleasure in technology as they identify themselves with it and take pride in their technological competence, which are all crucial elements in the individual identities and shared culture engineers (Faulkner, 2001, p. 88) [9]. Boys have more positive feelings about computers than girls, and they like computers and are more interested in them (Sanders, 2005, p.10) [10]. They also not hesitate to compete with their female peers to insure better chances of academic success; as Acker's (1993, p. 259) [11] female participants revealed in his study "when it comes to computers, boys are like sharks". Another reason is highly likely to be that students are not motivated if they do not have sufficient confidence in using technology for learning. Technology may cause students to fear the topic, skill, or situation because they have negative or inadequate experience in using technology for learning previously (Yau \& Cheng, 2012, p. 2) [2].

Fortunately, digital technologies have brought a new relationship between women and machines. Women, rather than men are uniquely suited to life in the digital age (Wajcman, 2007, p. 291) [8]. Today, men and women use technology in a much contrasted manner as our society is moving toward a "digital society" (Pujol \& Montenegro, 2013, p. 178) [4]. Sanders (2005, p.10) [10] noted that although boys have more confidence and positive feelings about computers than girls, some statistics found that males and females' confidence in computer ability was equal, but females tend to underestimate their technology skills.

As Cynthia Cockburn (cited in Faulkner, 2001, p. 90) [9] once argued, technology itself cannot be fully understood without reference to gender, so one cannot understand gender without reference to technology. Therefore, while men have an instrumental use of the internet, women use it for 
training, communication, and care-giving (Pujol \& Montenegro, 2013, p. 175) [4]. Weber \& Custer $(2005$, p. 55) [12] found that boys were interested in how things work, and girls prefer more socially relevant topics such as the environment, people and the application of this knowledge to social conditions. Thus, the disproportionate lack of involvement and participation of females has been attributed to curriculum content that is biased towards males' interests.

Numerous feminists believe that women function in different ways than men and that their ways of knowing have much to offer in the reconstruction of theory (Zuga, 1999, p. 4) [3]. More specifically, cultural feminists argument is that there are differences in the way women experience and therefore think about the world. For example, female enjoy working on design activities including a focus on problem-solving or socially relevant issues. Females are more interested in activities that support and facilitate communication, and inter-personal interaction, which has been neglected by the literature (Wajcman, 2000, p. 447) [13].

Males are more interested in technology-related topics such as building activities involving machinery and tools (Weber \& Custer, 2005, p. 60) [12]. Weber \& Custer (2005, p. 66) [12] also added that female interest increases if computer is used as a tool to create something like a multimedia presentation, but not if the focus is on learning how to program computers. As Bray (2007, p.38) [14] noted, women may have to use machines in the workplace or in the home, but they neither love nor seek to understand them: they are considered passive beneficiaries of the inventive flame.

Numerous research has been undertaken to care about gender gaps and differences in the field of science technology. Nevertheless, male and female students' differences studying in applied foreign languages have been overlooked in the literature by being put in mixed gender groups.

Adair-Hauk and Colleagues (1999, p. 280) [15] reported the findings of their research regarding the integration of technology-enhanced language learning (TELL), in a college level French course. 33 students studying in different majors participated in the study. 17 students were placed in the treatment group, and 16 students were placed in the control group in a way that both groups did not have significant differences in age, sex, point average and year in college.

Adair-Hauk and Colleagues found that 14 of the students in the treatment group had met their learning goals, two almost had, and one did not. In the control group, 11 of 15 students had made clear progress, four had made some progress, but not as much they expected. The treatment group performed as well as the control group in listening, but outperformed the control group in reading and writing. According to Adair-Hauk and Colleagues, studies of motivation and attitude toward writing have produced more positive results. Computer composing reduced blocking problems and improved the students' overall attitude toward writing in English. They also reported that the multimedia activities of the TELL challenged the students to take greater responsibility in working harder to learn French successfully.

Quite similar to Adair-Hauk and Colleagues' study, Yang \& Chen (2007, p. 860) [16] investigated their participants' views on the integration of internet tools in language learning activities. 44 $10^{\text {th }}$-grade male students and their teacher, from a single boy's senior high school, joined a technology-enhanced language learning (TELL) project in Taiwan, known as "Advanced Joint English Teaching" (AJET). As the students participated in six internet activities such as e-mailing, English home-page design and video conferencing, they reported that enjoyed learning English this way but had differing opinions regarding its benefits. Learning English is an attempt to communicate with people in a new language (Yang \& Chen, 2007, p. 861) [16], but the Taiwanese language environment does not offer this chance. Thus, it has become important to include the internet in the teaching methodology to help ESL students be in contact with foreigners. 
In agreement with Asied \& Pathan (2013, p. 65) [17], researchers, have reported that students' writing skills can be improved via networked computers. Yang \& Chen's (2007, p. 860) [16] reported in their study that students showed notable learning achievements when they used the internet during learning activities on their personal web pages Yang \& Chen's (2007, p. 867) [16]. The designs of students web pages a great variety of imagination, used various solving-problem skills to analyze and synthesize the data they collected from the internet.

In another study, Asied \& Pathan (2013, p. 61) [17] stated that technology has become inseparable part of today's world and this is also true with the field of foreign language instruction. Therefore, they wanted to investigate the advantages of computer technology in English as a Foreign Language (EFL) and its implications in foreign language situations like Lybia. The use of computer technology in EFL classrooms is interesting for developing EFL learners' listening comprehension skills, speaking skills and reading comprehension skills. Regarding the students' writing skills, the computer technology is one of the most effective tools to teach writing Asied \& Pathan (2013, p. 65) [17]. Cunningham's (2000, cited in Asied \& Pathan, 2013, p. 65) [17] report on his teaching methods revealed that his students thought that their writing class was more industrious when he used word processing software with his students. Students were more motivated to learn the subject because it brings more challenging tasks in the target language in a real, authentic situation.

As a logical sequence, Iacob's (2009, p. 141) [18] study can be taken into account because it aimed to evaluate the efficiency of the computer assisted English classes and to emphasize the necessity of developing sound methodological strategies adjusted to the technology. The use of technology leads to greater success, as students use more visuals and make use of their listening skills, they become more involved in class (Iacob, 2009, p. 142) [18]. In agreement with Asied \& Pathan (2013, p. 65) [17], Iacob stated that technology helps students improving their listening and reading skills, but reported that computers cannot easily assess speaking and writing skills due to limitations of controlled speaking and writing practice. In accordance with Yang \& Chen (2007, p. 861; Byfield and colleagues, 2016, p. 42) [16] [19], the benefits and advantages of technology is that it provides students with a more interesting and challenging learner-centered explorative approach.

By contrast, Shyamlee \& Phil (2012, p. 151) [6], stated that technology is not only used to improve both visual and auditory senses of students, but also help students gain more confidence and self-esteem in the world of media technology because it plays a positive role in promoting learning activities and communications skills such as spoken English, reading, listening and interpreting, which is in line with Byfield and colleagues (2016, p. 39) [19] who wrote that previous has confirmed that the impact of technology on English learners' literacy development.. Students can focus more on their learning tasks; they feel that their teachers are not systematically evaluating their progress.

Finally, technology has become an integral part of all educational systems worldwide, and the presence of information technology in English language teaching has become inevitable. Because technology has brought changes in the school for teachers and students alike, Al-Mohannadi \& Derbel (2014, p. 182) [20], have conducted a study consisting of 60 students enrolled in one higher education institution and grouped them into two groups; a technology group $(\mathrm{N}=60)$ and a non-technology group $(\mathrm{N}=60)$. Their participants were students in both groups were selected from different classes and were English majors planning to teach English after graduation.

Al-Mohannadi \& Derbel wanted to investigate the impact of integrating information technology in ELT on EFL learners' motivation and interest. Their results (2014, p. 184) [20] show that participants in both groups shared positive perceptions toward information technology and its 
embedding within language teaching. Participants in both groups had high levels of interest. By contrast, results of the motivation component are shown in a different light. Participants from the technology group reported higher motivational levels compared to the non-technology group. 90 per cent of the students from the technology group brought to the attention of the researchers that they had already attended an IT English language teaching class; the remaining students were not as much motivated. In the non-technological group, participants revealed surprising details. 79 per cent of the participants reported that their EFL class was not successful in motivating them to study at all; 16 per cent of the students were just not motivated, and only 5 per cent thought the class was motivating. The difference of motivation between the technological group and the non-technological group is important to be taken into consideration.

\subsection{Conclusion of the literature}

Previous research in Science technology has shown that male students feel more confident than female students in their use of technology. By contrast, even though female students enjoy educational science curriculum, they feel apprehensive in using technology because they have suffered discrimination due to sexism from their male counterparts. Unlike the abundant research in Science Technology on gender, the literature in the domain of Applied Linguistics shows that no previous investigations have investigated gender issues. Therefore, little is known if the lack of motivation experienced by male and female students to participate in computer class activities is due to sexism or the class curriculum.

Because male and female students enrolled in an English translation class in the Department of Applied foreign languages in National Taipei college of Business seem reluctant to use computer technology, this research aims to find out the students' insights of using technology in the classroom, and to bring a discussion on a suitable learning content promoting female students interests in computer technology, which in turn could encourage male students' participation. To accomplish this goal, the following research questions will be addressed:

1. Are male and female students enrolled in Applied Foreign Languages equal in their use of educational technology?

2. Is female's lack of motivation of using technology due to curriculum or sexism?

3. What are the perceptions of male and female use of technology?

\section{METHODOLOGY}

\subsection{Context and Participants}

The research was conducted at the public university of National Taipei University of Business, located in Taipei city, Taiwan. The samples were taken from 48 students; they were attending 影 視翻譯 (Film Translation) course. Students in class 二技夜外語二甲 (= 18 males and 30 females) were in the fourth semester. Their age ranged from 20 to 40 years old.

\subsection{Procedure}

The survey took place In April 7, 2016, and lasted for two weeks. This study used the Murphy, Coover, \& Owen's (1989, p. 68) [21] Computer Self-Efficacy Scale (CSES). The Likert-scale items ranged from "1" (Strongly Disagree) to "5" (Strongly Agree). A higher score on an item indicated a greater degree of confidence in that element of the basic skill set assessed by the scale. The validity of the question items was thus already validated and its reliability was already established. The following week, 6 students (three males and three females) volunteered to answer an interview. The interview questions were based on Honeck' s (2013) [22] questionnaire model on students' English writing skills perceptions and their level of English of academic tests. 
The interviews were conducted with the students according to Mack \& others' (2005, p.31) [23] logistics of interviewing, which include the responsibility of the interviewer to prepare for the interview, to interview the participants thoroughly, and to document the interview. In addition, Strauss \& Corbin's (2015, p.239) [24] provided more detailed information on documenting the interview such as taking backup notes, expanding notes as soon as possible after the interview, and making an analysis of interview with memos. Moreover, Strauss \& Corbin's Axial coding was useful in creating in categories and concepts to better describe and interpret the interviewees' comments.

Finally, the participant observations were conducted according to Mack \& others' (2005, p.13) [23] logistics of observations, which include an overview of Participant Observation, ethical guidelines, logistics of participant observation, and how to be an effective participant observer.

\section{RESULTS}

\subsection{Results of the questionnaire}

All the students enrolled in the "English Translation" class, responded to the questionnaire. Table 1 , shows the results of the independent T-test regarding the differences in gender's use of computers. As can be seen, most of the students have equal abilities in using computers, and none of the items of the questionnaire differ significantly.

Table 1. T-tests of male and female students using computers

\begin{tabular}{|l|c|c|c|c|c|c|c|c|}
\hline I am confident to... & \multicolumn{2}{|c|}{ Male Students } & & Female Students & & & \\
\hline $\begin{array}{l}\text { Manage files on } \\
\text { computers }\end{array}$ & $\mathrm{N}$ & Mean & $\mathrm{SD}$ & $\mathrm{N}$ & Mean & $\mathrm{SD}$ & $\mathrm{t}$ & $\mathrm{p}$-value \\
\hline $\begin{array}{l}\text { use of software on } \\
\text { computers }\end{array}$ & 18 & 5.86 & 1.38 & 30 & 7.01 & 1.28 & -0.86 & $0.35^{* *}$ \\
\hline $\begin{array}{l}\text { Use of hardware on } \\
\text { computers }\end{array}$ & 18 & 3.95 & 0.93 & 30 & 6.42 & 1.17 & -0.52 & $0.6 * *$ \\
\hline $\begin{array}{l}\text { work on a computer } \\
\text { network or system }\end{array}$ & 18 & 3.51 & 0.82 & 30 & 5.17 & 0.94 & 1.26 & $0.26^{* *}$ \\
\hline $\begin{array}{l}\text { deal with computer } \\
\text { problems }\end{array}$ & 18 & 2 & 0.47 & 30 & 3.69 & 0.67 & 1.93 & $0.05^{* *}$ \\
\hline
\end{tabular}

(*) significant at $\mathrm{p}$-value $<0.05$, and (**) insignificant at $\mathrm{p}$-value $>0.05$

Manage files on computers - included the items "enter and save data into a file, view a data file on monitor screen, copy an individual file, get rid of files, delete information on data file, organize and manage files, handle a floppy disk correctly, and copy a disk". From table 1 above, it can be seen that the outcome of this analysis for this sub-characteristic regarding the management of files on computers is not consistent. The Pearson Correlation Coefficient test is positive $(0.35)$ at $\mathrm{P}$-Value $>0.05$; therefore, there is no significant difference between male and female students.

Use of software on computers - included the items "store software correctly, exit from a program software, getting a software running, understand terms of software, understand input/process/output, writing simple software programs, and use a variety of programs". From table 1 above, it can be seen that the outcome of this analysis for this sub-characteristic regarding the use of software on computers is not consistent. The Pearson Correlation Coefficient test is positive $(0.22)$ at $\mathrm{P}$-Value $>0.05$; therefore, there is no significant difference between male and female students. 
Use of hardware on computers - included the items "make selections on screen menu, use computer to write a letter or essay, work on a personal computer, analyze number data, learn advance skill in program, understand terms of hardware, describe functions of hardware, move cursor on monitor screen, and use a printer to make a hard copy". From table 1 above, it can be seen that the outcome of this analysis for this sub-characteristic regarding the use of hardware on computers is not consistent. The Pearson Correlation Coefficient test is positive (0.60) at P-Value $>0.05$; therefore, there is no significant difference between male and female students.

Work on a computer network or system - included the items "log onto a computer system, log off a computer system, $\log$ on a computer network, log off a computer network, working on a mainframe computer, and working on a computer network". From table 1 above, it can be seen that the outcome of this analysis for this sub-characteristic regarding the use of computer networks and systems is not consistent. The Pearson Correlation Coefficient test is positive (0.26) at $\mathrm{P}$-Value $>0.05$; therefore, there is no significant difference between male and female students.

Deal with computer problems - included the items "use the user's guide when needed, get help for problems in computer, troubleshoot computer problems explain why a program will not run". From table 1 above, it can be seen that the outcome of this analysis for this sub-characteristic regarding the dealing with computer problems is not consistent. The Pearson Correlation Coefficient test is positive $(0.26)$ at $\mathrm{P}$-Value $>0.05$; therefore, there is no significant difference between male and female students.

\subsection{Results of the interviews}

In total, 7 students were randomly selected and were willing to participate to the interview process after they completed their mid-term exam on week 9 . Table 2 presents the profile of the interviewees. In this Table, $\mathrm{F}$ refers to female interviewees while $\mathrm{M}$ refers to male participants.

Table 2. Profile of the interviewees

\begin{tabular}{|c|c|c|c|c|c|c|}
\hline Interviewee & 1 & 2 & 3 & 4 & 5 & 6 \\
\hline Gender & $\mathrm{M}$ & $\mathrm{F}$ & $\mathrm{M}$ & $\mathrm{M}$ & $\mathrm{F}$ & $\mathrm{F}$ \\
\hline
\end{tabular}

After the questionnaire was completed, the researcher invited the new class to respond to an interview. The participants (= 3 males and 3 females) responded voluntarily to the interviews. Because they were night time students, they had little extra time to spare to retrospect on their learning experiences. Nevertheless, the researcher used Strauss \& Corbin's (2015) [24] Grounded theory to categorize the interviewees' answer into concepts. The interview included 8 items which addressed their English writing skills and their computer use when writing in English.

For the first item, How do you feel about writing in English? And what is your experience?, the raw data was developed under the concept of "writing for pleasure". Female students responded that they have some experience at writing, while male students do not. For example, participant 2 is used writing emails and letters at work, participant 5 may writes letters in English sometimes and participant 6 is used to write a diary to express her feelings, and happy events of the day. By contrast, male student 4 said that although he has and advanced level in English because he passed the TOIEC test, his writing skills are poor because he is not a good speller; the two other male interviewees 1 and 3, said that they only write in English for completing homework and practicing for English exams.

The second item, What is your English level?, included a raw data very similar for all the participants which was categorized under the concept of "Impact of learning English". Participant 2 and 4 are confident that they have a high level of fluency and feel confident in their ability to communicate fluently, while student 5 believed her fluency is limited as she only has reached an 
intermediate level. The three other interviewees said that they are at a beginner level and do not feel very confident with their English writing.

The third item, Do you often use Chinese to type on the computer?, was coded as "the computer". Although students revealed that that they are used to type emails in Chinese, participant 3 reported that he may occasionally write short essays in Chinese, but that it is still difficult at his level of fluency. Participant 2 revealed that she uses the computer both at school and at work. Other participants' use of the computer to write letters is limited because they mostly use if to surf the internet or send brief text messages online.

The fourth item, What are your weaknesses and strengths in English?, was coded as "the English writing experience" because students feel as being beginners in their writing skills and are cautiously entering a whole new field of study when asked to write in English in the classroom. The students revealed that they feel they cannot write very well and that they could write better if they could improve and expand their vocabulary knowledge. For example, Participant 2 mentioned that although she has clear thoughts on how to express herself, and that has learned to organize her ideas, she still needs to check the dictionary all the time. Similarly, participant 6 said that "it's difficult to key in the words you don't have enough words to express yourself; I think that my English writing would be better if I can check the spelling on the internet".

The fifth item, What do you think about using the computer to write in English?, was coded as "breaking the wall of silence" because the researcher would finally have the chance to hear the hidden reasons behind the students reluctance to use the computer in the classroom. Although the students recognized that the use of the computer is useful because it has the function of warning for misspellings, can help correcting grammar mistakes and some syntax errors, some students revealed that their lack of knowledge in English writing and prevents them from participating during class. their lack of confidence in their writing ability was expressed by Interviewee 4 who mentioned that "It surely could be easier to write, but I am I am not a good speller in English"; similarly, participant 5 mentioned that she preferred using traditional writing methods by saying that "hand-writing is useful to me, and the teacher can correct my writing on the paper".

The sixth item, Are boys better skilled at using computers than girls? Was coded "equality in technology" because the majority of students they have equal skills at using computers. Participant 1 thinks that there is a very small difference between male and female students because boys are good at logical thinking. Interviewee 4 reported that "males and females are equal at computer stuff, although they might not be as familiar with hardware and software knowledge; but they may be may be more experienced in real life". While female 5 reported that there is practically no difference between male and female students, she also added that "boys might have more knowledge of computer hardware because they use more video games than girls".

The seventh item, What would you do if a classmate did not know how to use the class computer?, was coded "friendship and technology" because the answer to the interview show that, with some variations in their responses, most students would be willing to help their classmates if they encountered some difficulties while using the class computer. For example, while participant 1 answered that he would just ignore his classmates, participant 6 said "I would prefer waiting first in case another classmate would be willing to help. If s/he has problems again, maybe you (the teacher) will call me".

The final item "Have you ever heard any comments, dirty jokes, and negative criticism from boys to girls regarding their technology computer use ability?, was coded "respecting the feelings of others". Overall, the students have not said nor heard any of these negative comments toward girls. Participant 2 explained that "this situation may be happening in foreign countries, in Europe 
or the USA. In Taiwan, we don't usually criticize our classmates openly". In addition, interviewee 4 mentioned that "boys and girls may tease each other on their lack of experience of technology or computer use. We may make a joke to one another, but we are still friendly to each other".

\subsection{Observations of the students attending "Film Translation" class}

The observation was conducted at the public university of National Taipei University of Business, located in Taipei city, Taiwan. The samples were taken from 48 students; they were attending the “Film Translation" course. Students in class 二技夜外語二甲 (= 18 males and 30 females) was in the fourth semester. The observation took place from week 1 until week 7.

Some students had attended the same course the previous semester and were surveyed on the usage of their mobile phones in translation activities (Blasco, 2016). The introduction of this new course "Film Translation" to the students took place on week 1, and presented the concept of paraphrasing and translating movie plot summaries. On week 2 to 4 , the researcher introduced YouTube video trainings on basic paraphrasing skills. The researched planned that the class would watch an American movie scheduled on three sessions, and would be presented with a different 50 to 60 words-summary plot of the same movie each week.

The researcher learned that his students had never performed paraphrasing activities in their past studies. Therefore, he explained and reviewed the paraphrasing steps with the students over a month. As they tried to perform their paraphrasing activity, they appeared lacking confidence in their writing skills abilities. In addition, due to time constraints, the researcher decided that the students would perform one sentence a week over three weeks, instead of doing one plot summary plot at each session.

On weeks 5 to 8 , the teacher noticed that students were strongly lacking eagerness to present their writing samples in English on the class computer - they remained very quiet and uncooperative. Fortunately, three female students agreed to submit their writing samples to the teacher and wrote them on the class computer. After they finished writing their sentence, the researcher brought a discussion on some grammatical points and syntax. This way, everyone could visualize different suggestions, which would make the class learning more valuable. In addition, as it was a translation movie class, the teacher asked the students to review their paraphrased sentences and to translate it in Chinese as their weekly homework. They were not requested to type their Chinese translation on the computer on their next class. These learning materials were used as testing samples for their mid-term examinations.

As the research previously learned about gender differences in science technology, he wondered about the differences between male and female students in applied foreign languages: "why were male students unwilling to participate, and why did too few female students agree to contribute to class learning"? These questions lead the researcher to finding out how to give female students more confidence in their use of computer in educational technology.

\subsection{Discussion and conclusions}

This study aimed to investigate the perceptions of students' use of technology in the field of English applied foreign languages and to promote female students' interests in educational technology. Three research questions were posed to do just this, and the subsequent raw data drawn from the interviewees was analyzed by using Strauss \& Corbin's (2015, p.239) [24] research demonstration projects. 
The answer to the first question "Are women equal to men in their use of modern technology?, is in agreement with Sanders' (2005, p.10) [10] findings that male and female students studying in Applied Foreign Languages are equal in their use of computer technology. The results of the questionnaire revealed that the difference between male and female students was not significant. Nevertheless, statistical results also show that female students have a higher mean than male students on all the items.

Because the statistical results of the questionnaire were not significant, it is highly likely that students' differences might also be placed on their learning styles. For example, Lo's (2012, p.54) [23] and Chu and Nakamura (2010, p.31) [26] studies of Taiwanese students' L2 learning styles indicated that "a great number of students used tactile style the most, and the individual style the least" and that "stronger preference for group style because ESL students enjoy learning English actively in class". Students are active during class activities, but passive when the teacher is giving a lecture, and reflective when they have to do activities on their own. In addition, female students are more interested than males in activities that support and facilitate communication (Wajcman, 2000, p. 447) [13].

The raw data of the second research question "Is female's lack of motivation of using technology due to curriculum or sexism"? was coded under the concept of "feeling of commitment". The general lack of contribution from the students can be attributed to the learning which is planned and guided by the teacher, rather than with sexism. The reason for this is that the $8^{\text {th }}$ item of the interview "Have you ever heard any comments, dirty jokes, and negative criticism from boys to girls regarding their technology computer use ability?, revealed that girls are not the recipient of negative comments. Most of the students have never heard or said dirty jokes, but they may sometimes gently tease each other. In addition, the answer to the seventh item, What would you do if a classmate did not know how to use the class computer?, shows that most students would be willing to help their classmates if they encountered some difficulties while using the class computer. This is in direct opposition with Acker's (1993, p. 259) [11] findings that "when it comes to computers, boys are like sharks".

The third research question was concerned with "the perceptions of male and female use of technology", and was coded "Experiencing technology". When asked what about their experiences of writing in English, 95\% reported that they are not used to write in English and limit their practice to writing emails and short notes either in English or in Chinese. When investigated on their perceptions of using computer to write in English, all the students recognized that the use of the computer is useful because it can help them correcting grammar mistakes and syntax errors. Because of their lack of confidence, there is a high possibility that they might also be underestimating their technology skills to write in English (Sanders, 2005, p.10) [10].

The results of this study indicated that female's lack of motivation and males' passivity in using technology National Taipei University of Business is highly likely to be due to the learning which is planned and guided by the teacher. Male and female students share similar preferences for group and may also become passive-reflective learners when attending a lecture; they differ subtly in their use of computers. It is very likely that male and female students can support each other to complete learning activities and assignments (Lo's 2012, p.60; Chu and Nakamura, 2010, p.31) [25] [26] because both genders can efficiently work as a team as discrimination is inexistent. According to Altun $(2015$, p.1) [7], students learning a foreign language strongly believe that technology-based instruction should be implemented in language learning process, and concludes that technology-based instruction leads to accomplishment. Similarly, participants of this study revealed that the use of computers is useful to them to correct their grammar and syntax. 
Nevertheless, the only use of computer functions and internet support is not enough. Teachers should only use them as an essential teaching tool to motivate students to learn. According to Chin (2000, p.1) [27] students can also "learn how to transfer their knowledge of grammatical concepts from oral language to written language". In order to do just that, the teacher will have to use his students' writing as a foundation for discussing grammatical concepts. For example, after students have watched a movie, they are given a plot summary to paraphrase. Students will put their knowledge in common to write and create new sentences as their paraphrasing activity. Whyte's (2010, p.1) paraphrasing activities provide relevant and useful activities helping students with grammar challenges while learning how to write in English.

After the students have completed their paraphrasing activities, the teacher can increase his students' interest during the lesson by requesting them to use the class computer to type their sentences in English on the keyboard (Weber \& Custer, 2005, p. 66) [12], which will be seen on the overhead projector. As can be seen in the statistical results of the questionnaire, female and male students confidence does not differ signicantly, but because female students have a higher mean on the item of using a computer hardware, they are highly likely to gain more confidence than male students when given learning activities that match their learning interests. In turn, male students will be encourage to perform computer activities to contribute to class learning more often. Besides, while female students use the computer as multimedia presentation, the teacher can deliver a mini lesson on a problematic grammar point when modifiers, conjunctions are misplaced (Chin, 2000, p.1) [27] these mini lessons will reduce the time spent on lectures, and increase allotted time for group discussions.

Next, the teacher asked students to re-check their paraphrased sentences, which can be seen on the white screen, and make appropriate corrections of grammar errors by looking up in their textbooks or grammar books, which is similar to a "user's guide when help is needed". Once again, the teacher needs to take into consideration his students' learning needs by providing them with instruction on the grammatical elements that most affect their students' writing ability to write effectively (Chin, 2000, p.3) [27].

Finally, the teacher assigned his students to translate their sentences in Chinese as their homework because the course was titled "Movie Translation". As statistical results of the questionnaire show that female students have a higher mean for managing files on a computer, the teacher wanted to assign mixed groups to complete their translation assignments, and female students would be very likely to encourage male students to "use a printer to make a hardcopy for their homework". This item is relevant to this study because female students' interests in technology can be increased by being given responsibilities that are important to the teacher such as organizing the print out of all the students' completed activities and to design a file or booklet to classify all the students' homework (Weber \& Custer, 2005, p. 60) [12]. That way, the teacher can easily keep track of the work performed in class. It goes without saying that male and female students can be challenged by switching activities; male students can be challenge by getting out of their learning passivity and being given more responsibility to complete their assignments, but a balanced learning environment should also be preserved.

There are some limitations to this study. First, the number of participants of this study was small. More participants could have brought more insight into the gender differences in using computers. Second, because of time constraints, the interview was conducted with only six participants because they are working students, having little time to spare for this research. Third, the teacher does not have access to students' grades and GPAs to perform correlations with their learning behaviors while using computers; it is thus recommended that future studies verify if female participation in class, when using computers and doing design activities, has increased along with their academic achievements. 
International Journal on Integrating Technology in Education (IJITE) Vol.5,No.2,June 2016

\section{ACKNOWLEDGEMENTS}

I would like to express my sincerest thanks and appreciation to my students and participants of National Taipei University of Business, who agreed to bring their contributions to this study, and without whom this paper would not have been completed.

\section{REFERENCES}

[1] Wikipedia.

(2016).

Educational

technology

retrieved

from

https://en.wikipedia.org/wiki/Educational_technology

[2] Yau, H.K., Cheng A. L.F., Gender differences of confidence in using Technology for learning. The journal of technology studies, 38(2), p. 74-75.

[3] Zuga, K.F. (1999). Adressing Women's way of knowing to improve the technology education environment for all students. Journal of Technology Education, 10(2), 57-71.

[4] Pujol, J., Montenegro, M. (2013). Technology and feminism: a strange couple. Revista deestudies sociales, 51, 173-185.

[5] Wang, Y.H. (2012). Still Gender Boundary? Exploring Woman University Technology Students'Doing Gender and Doing Technology. International Journal of e-Education, e-Business, e-Management and e-Learning, 2(1), 34-39.

[6] Shyamlee S.D., \& Phil, M. (2012). Use of technology in English language teaching and learning:An analysis. International Conference on Language, media and Culture, 33, 151-156.

[7] Altun, M. (2015). The integration of technology into foreign language teaching. International Journal on New trends in Education and Their Implications, 6(1), 22-26.

[8] Wajcman, J. (2007). From women and technology to gendered technoscience. Information,Communication and Society10(3), 287-296.

[9] Faulkner, W. (2001). The technology question in feminism: a view from feminist technology Studies. Women's studies International Forum, 24(1), 79-95.

[10] Sanders, J. (2005). Gender and technology in Education: A research review. Handbook of Gender in Education. Sage Publication, London.

[11] Acker S. (1993). Gender issues in education for sciences and technology: current situation and prospects for change. Canadian Journal of Education, 18(3), 255-272.

[12] Weber, C., \& Custer, R. (2005). Gender-based preferences toward technology education content,activities, and instructional methods. Journal of Technology Education, 16(2), 55-71.

[13] Wajcman, J. (2000). Reflections on gender and technology studies: in what state is the art? Social Studies of Science, 30(3, 447-464).

[14] Bray, F. (2007). Gender and Technology. The Annual Review of Anthropology, 36, 37-53.

[15] Adair-Hauk, B., Willingham-McLAin, L., Youngs, E.B. (1999). Evaluating the integration of technology and second language learning. Calico Journal, 17(2), 269-306.

[16] Yang, S., C., Chen, Y-J. (2007). Technology-Enhanced language learning: a case study. Computer in Human Behavior, 23, 860-879.

[17] Asied, S., M., Pathan, M., M. (2013). The use of computer technology in EFL classroom:advantages and implications. International Journal of English Language \& Translation Studies,1(1), 61-71.

[18] Iacob, I. (2009). The effectiveness of computer assisted classes for English as a second language.Annals. Computer Science Series, 7(1), 141-148.

[19] Byfield, L., Shelby-Caffey, C., Bacon, H., Shen, X. (2016). Digital literacy and Identity formation in 21st century classrooms: implications for second language development.International of Applied Linguistics \& English Literature, 5(1), 39-45.

[20] Al-Mohannadi, A., Derbel, E. (2014). The effects of embedding information technology within ELT on EFL learners' motivation and internet. International of Applied Linguistics \& English Literature, 3(1), 181-186.

[21] Murphy, C.A., Coover, D., \& Owen, S.V. (1989). Development and validation of the computer self-efficacy scale. Educational and Psychological Measurement, 49, 893-899.

[22] Honeck, A.Y. (2013). Assessing perceived writing self-efficacy beliefs in the community college environment. Master of Arts in English as a Second Language. Hamline University St. Paul,Minnesota.

Retrieved

from 
file:///C:/Users/CCU/Downloads/Alycia\%20Honeck\%20Capstone.pdf

[23] Mack, M., Woodsong, C., McQueen, K., M., Guest, G., Namey, E. (2005). Qualitative Research ethods: a data collector's field guide. Family Health International,North Carolina,USA.Retrieved fromhttp://www.fhi360.org/sites/default/files/media/documents/Qualitative\%20Research\%20Methods \%20-\%20A\%20Data\%20Collector\%27s\%20Field\%20Guide.pdf

[24] Strauss, A., Corbin, J. (2015). Basics of qualitative research: Grounded theory procedures and techniques (4th ed.). Thousand Oaks CA: SAGE Publications.

[25] Lo, M.L. (2007). EFL learning strategies and perceptual learning style preferences of vocational high school students in Taiwan. Unpublished master's thesis, National Taiwan University of Science and Technology, Taiwan, ROC.

[26] Chu, M., \& Nakamura, T. (2010). A study of Chinese and Japanese college students' L2 learning styles. Asian and Culture History, 2(2), 30-44.

[27] Chin, A.B. (2000). The role of Grammar in improving Students' writing. University of Montana. Retrieved from http://people.uwplatt.edu/ ciesield/graminwriting.htm

\section{Author}

I grew up and studied in the South of France and earned a bachelor degree in Marketing. While studying in France, I developed an early interest in international relations while learning English. I lived and worked in the United Kingdom for three years, and I moved to Taipei with my wife in 1999. Having a background in cultures of these countries, and being an independent user of the Chinese language as well, I have developed a curious mind regarding the teaching of English for Business Purposes. Due to this, while as I was working as an English and French and teacher

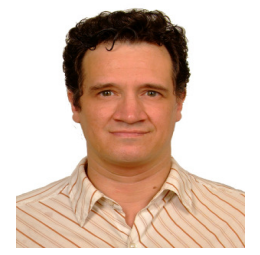
in Taipei, I studied in both National Taiwan University of Science and Technology in the department of Applied Foreign Languages as well as National Taipei University, Global MBA program.

As a lifelong learning project, I decided to pursue a PhD in education in 2012, at Zhong Zheng University, located in Jia Yi. The purpose of my study is to earn a doctoral degree to support the teaching my business skills gained from NTU Global MBA program, which are relevant to the teaching of English for Business purpose to University students.

My study at the Global MBA program combined with the teaching of foreign languages provided me with the opportunity to join Taipei college of Maritime technology, located in Tamsuei, and to gain my first experience at teaching English for commercial and leisure purposes. As I taught English for more than three years, I came to understand Chinese learners better and apply my learning in Applied Foreign Languages to develop teaching materials that were adapted to their learning styles.

I am currently teaching English in National Taipei University of Business, located in Taipei. Courses such as film translation and business letters and international correspondence provide me with new perspectives to teach as English as a foreign language focused on business purposes and which are adapted to students' learning needs. 